\title{
Extended Enterprise Metrics: The Key To Achieving Synthesized Effectiveness
}

John W. Kamauff, (E-mail: jkamauff@loyola.edu), Loyola College in Maryland Darlene Brannigan Smith, (E-mail: dsmith@loyola.edu), Loyola College in Maryland Robert Spekman, University of Virginia

\begin{abstract}
In this paper we argue that the Extended Enterprise is a natural response to changing competitive dynamics and is predicated upon adapting some of the traditional performance measures. We examine how the constructs of the Balanced Scorecard, Economic Profit (or Economic Value Added) and boundary spanning metrics such as the cash-to-cash cycle are useful tools for developing metrics for the Extended Enterprise. We illustrate that when these measures are jointly adopted they can help to drive the integrating behaviors that epitomize the truly revolutionary Extended Enterprise. The key phrase here is integrative - what is good for one must be good for all since the true competitive battle is fought supply chain against supply chain.
\end{abstract}

\section{Introduction}

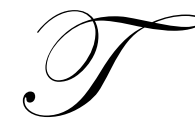

he Extended Enterprise is seen as the next level of supply chain integration. An Extended Enterprise comprises the entire set of collaborating companies both upstream and downstream, from raw material to end-use consumption, that work together to bring value to the marketplace (Davis and Spekman, 2004). The Extended Enterprise advantages derive from a firm's ability to quickly use the entire network of suppliers, vendors, buyers, and customers. The information flows that define coordination and collaboration among network members not only link disparate information sources, they provide an opportunity to build knowledge-based tools. Companies engage in longer term partnering relationships built around mutual goals and accompanied by a very rich and deep information exchange. Members see their destinies as interdependent serves, which is key in differentiating the Extended Enterprise from other loose confederations of buyers and suppliers. The fact that success is now a function of the collective performance of the enterprise, and not individual firm actions, signifies a significant change: the operative words become seamless and transparent.

In the final analysis, the objective of every Extended Enterprise is to maximize the overall value generated. It is important to note that members of the Extended Enterprise recognize the necessity of maximizing value for the marketplace and for the entire network of suppliers. The gains, benefits, and costs savings should be felt systemwide throughout the Extended Enterprise. Thus, measurement of and within the Extended Enterprise is of paramount importance. Measurement influences the ability to conceptualize the Extended Enterprise and, more importantly, it affects the behavior that impacts the capability to operationalize the Extended Enterprise. The ability to track performance levels is critical, as is the awareness of available tools and techniques in use throughout the Extended Enterprise. To paraphrase an old adage, "You cannot imagine what you do not measure!" What gets measured gets rewarded, what gets rewarded gets done!

Yet one of the most significant mistakes that many companies make with regard to measurement - whether driving the Extended Enterprise or not - is pursuing measurement for measurement's sake rather than as a vehicle to drive expected behavior. Measurement is related to strategic direction and all three - strategy, performance and metrics - should be in synch. Strategic intent (direction) drives performance and its metrics, in turn, establishes the kinds of behaviors that support the goals and objectives of the entire set of collaborating supply chain members. To 
accomplish this we must achieve synergy across all levels of the supply chain. Synergy can be achieved by effective design, integration and implementation of key metrics that span the entire supply chain.

In this paper we argue that the Extended Enterprise is a natural response to changing competitive dynamics and is predicated upon adapting some of the traditional performance measures. We examine how the constructs of the Balanced Scorecard, Economic Profit (or Economic Value Added) and boundary spanning metrics such as the cash-to-cash cycle are useful tools for developing metrics for the Extended Enterprise. We illustrate that when these measures are jointly adopted they can help to drive the integrating behaviors that epitomize the truly revolutionary Extended Enterprise. The key phrase here is integrative-- what is good for one must be good for all since the true competitive battle is fought supply chain against supply chain

\section{Changing Competitive Dynamics Drive Alliances}

In an increasingly competitive business environment, the challenges facing companies have never been greater. Mega-mergers, sophisticated enabling technologies, and proven business practices have raised the bar among competing companies and supply chains. Networks of manufacturers are replacing vertically integrated industries. Manufacturers and service providers alike have greatly expanded customer and supply bases with the advent of the Internet and eBusiness technologies. These same technologies have empowered customers and consumers with substantially more information about products/services and access to a greater number of vendors. Companies, particularly those with very strong brands, are narrowing their focus by directing more resources at serving their customers and outsourcing manufacturing. Companies like Nike and Sara Lee, both brand-building companies, have outsourced much of their production. In addition, both the pharmaceutical and electronics sectors rely heavily on contract manufacturing, focusing on what they do well - the development and marketing of their products. In short, competition will be played out no longer by individual manufacturers but by alliances of manufacturers. ${ }^{1}$ To remain competitive, it is essential to balance the tradeoffs between cost, quality, and delivery both for the Extended Enterprise and its trading partners. Depending on the situation, optimization decisions can include customer needs, product/process design, manufacturing, distribution, transportation, supplier issues, and is all predicated on the willingness and ability to share information when, where, and how it is needed. Extended Enterprise optimization is necessarily geared toward achieving the following key goals:

- $\quad$ Responsiveness to customer demand

- $\quad$ Superior customer service

- $\quad$ Effective product/process delivery

- $\quad$ Rationalized inventory

- $\quad$ Rapid new product/service introduction

Each goal necessarily requires forming deep relationships (almost at the individual level) and developing a broad understanding of customer and supplier needs. To achieve this, the Extended Enterprise must leverage the Internet and information sharing strategies that help to make demand and inventory timelier than traditional EDI technologies. Finally, the Extended Enterprise that concentrates on identifying and delivering the core competencies that their customers demand use effective outsourcing and in-sourcing to shorten the time to market new products and services. Yet, none of these goals can be achieved without a shared set of values and norms that support, nurture and reward collaborative behaviors and attitudes. These goals cannot be sustained without such relationship-based characteristics as trust, commitment, and high levels of information exchange that pervade all levels of the supply chain Extended Enterprise Metrics. Most companies progress through a series of stages leading to effective enterprise integration, evolving from a single-firm orientation to a supply-chain "partnering" focus to an Extended Enterprise perspective. Therefore, to understand the evolution of metrics for the Extended Enterprise, it is important to consider the differences between traditional measures, enterprise measures, and extended enterprise measures. The following discussion examines how information technology, process, structure, people, information, and outcomes in an extended enterprise differ from the more traditional organizational structures. The unique characteristics of performance measurement in the extended enterprise are as follows:

\footnotetext{
1 IndustryWeek $4^{\text {th }}$ Annual Census of Manufacturers
} 
First, the focus of information technology is on cross-firm solutions that enable the free and honest flow of information to all supply chain partners. Second, processes and structures emphasize decentralization and participation throughout the supply chain with each partner given a say in how value is created and delivered to end use customers. It is not possible to deliver a supply chain-wide solution if enabling mechanisms do not foster participation across all extended enterprise players. System-wide thinking replaces both a procurement function and a single firm orientation. Third, people lie at the core of the extended enterprise. People trust, people share information and people must be equipped to address the change in perspectives that are required to be extended enterprise facile. It is essential that we recognize that most managers do not currently possess the skills or mindset needed to operate in an extended enterprise environment. Fourth, having enabling technology does not ensure that the right information is shared across companies. Workflow related information is necessary to make the process work. However, the ability and willingness to share company specific knowledge and expertise grants a competitive advantage to those willing extended enterprises.

\section{Traditional Measures}

Performance management in a traditional, single-firm perspective typically relies on functionally focused financial measures. For the most part, financial accounting measures tend to be historically oriented and do not provide a forward-looking perspective. They also typically do not relate to important strategic non-financial performance measures, like customer service, loyalty and product quality, and do not tie directly to operational effectiveness and efficiency. Within such traditional frameworks, each functional area measures its performance on its own terms, with individuals being evaluated based on their ability to meet objectives consistent with department (or at best, process) measures. Often sub-optimal and frequently satisficing, individuals working under these conditions tend to behave in a way that improves their own area's performance, frequently at the expense of others. When each functional area establishes its performance in isolation, it often leads to silos and conflicting organizational goals. Similarly, organizations that establish functional and process performance measurement systems in isolation from the other Extended Enterprise members face the same consequences of conflicting objectives and sub-optimal performance.

Table 1 lists a set of traditionally focused metrics across three functional areas. An examination of these metrics illustrates the potential for conflict.

Table 1: Traditional, Functionally Oriented Metrics

\begin{tabular}{|c|c|c|c|c|}
\hline Purchasing-Related & \multicolumn{2}{|c|}{ Manufacturing-Related Metrics } & \multicolumn{2}{|c|}{ Logistics-Related Metrics } \\
\hline $\begin{array}{l}\text { Material inventories } \\
\text { Supplier delivery } \\
\text { performance } \\
\text { Material quality } \\
\text { Material inventories } \\
\text { Unit purchase costs } \\
\text { Material acquisition } \\
\text { costs: } \\
\text { - Cost per purchase } \\
\text { order } \\
\text { - Dollars managed per } \\
\text { buyer } \\
\text { - Expediting Costs } \\
\text { Line items per buyer } \\
\text { Time per purchase order } \\
\text { No. of purchase orders } \\
\text { per buyer } \\
\text { Invoice errors }\end{array}$ & $\begin{array}{l}\text { Product quality } \\
\text { WIP Inventories } \\
\text { Adherence-to-schedule } \\
\text { Cost per unit produced } \\
\text { Setups/Changeovers } \\
\text { Setups/Changeovers } \\
\text { costs } \\
\text { Unplanned stockroom } \\
\text { issues } \\
\text { Bill of materials } \\
\text { accuracy } \\
\text { Routing accuracy } \\
\text { Plant space utilization } \\
\text { Process yields }\end{array}$ & $\begin{array}{l}\text { Line breakdowns } \\
\text { Plant utilization } \\
\text { Warranty costs } \\
\text { Source-to-make } \\
\text { cycle time } \\
\text { Percent scrap } \\
\text { Material usage } \\
\text { variants } \\
\text { Overtime usage } \\
\text { Production cycle } \\
\text { time } \\
\text { Manufacturing } \\
\text { productivity } \\
\text { Master schedule } \\
\text { stability }\end{array}$ & $\begin{array}{l}\text { Finished goods } \\
\text { inventory turns } \\
\text { Finished goods } \\
\text { inventory days of } \\
\text { supply } \\
\text { On-time delivery } \\
\text { Lines picked/hour } \\
\text { Damaged } \\
\text { shipments } \\
\text { Inventory } \\
\text { accuracy } \\
\text { Pick accuracy } \\
\text { Logistics cost } \\
\text { Shipment accuracy } \\
\text { On-time shipment } \\
\text { Delivery times }\end{array}$ & $\begin{array}{l}\text { Warehouse space } \\
\text { utilization } \\
\text { End-of-life inventory } \\
\text { Obsolete inventory } \\
\text { Inventory shrinkage } \\
\text { Cost of carrying } \\
\text { inventory } \\
\text { Documentation } \\
\text { accuracy } \\
\text { Transportation costs } \\
\text { Warehousing costs } \\
\text { Container utilization } \\
\text { Truck cube utilization } \\
\text { Premium freight } \\
\text { charges } \\
\text { Warehouse receipts }\end{array}$ \\
\hline
\end{tabular}


Operationally oriented (i.e., logistics or sourcing) measures have traditionally been veiled under the umbrella of cost reduction, JIT, and quality management. Today, these practices are necessary but not sufficient to remain competitive; they simply represent the minimum entry requirements. The evolving focus is on leveraging Web-based technologies to create highly responsive and efficient supply chains. Now there is greater emphasis on becoming world class and bench marking against the best in breed companies. Such data can be found in the IndustryWeek Census of Manufacturers ${ }^{2}$ that enables individual companies to understand how they compare against their peers with regard to performance metrics, management practices, and implemented technologies. The Census provides detailed performance metric benchmarks as well as implementation levels of initiatives and enabling technologies within specific industries, across "world-class" respondents, and for all respondents. The Census also addresses the key supply chain challenges facing manufacturers and provides the foundation for understanding the minimum requirements necessary to begin the revolutionary journey toward building the Extended Enterprise

The traditional functional focus on technology is transaction-oriented, usually directed only internally within the organization, with limited emphasis on decision support. The measures inherently reflect this emphasis: processing power, CPU speed, number of users and applications, etc. Here, technology becomes an end point, a goal to achieve, rather than being recognized as an enabler. All processes are inherently transaction focused with major attention given to cost reduction. Risk avoidance (i.e., financial risk avoidance) is a fundamental concern that is heightened by a focus on the single department or function. Information is defined as a key to power, and control constitutes a major consideration since bureaucracy rules the day. Outcomes are often limited to efficiency measures and are used to leverage denominator management. That is, management becomes fixated on cost reduction while simultaneously reducing the supply base and increasing the customer base. Clearly, an organization that relies on such traditional efficiency measures faces a competitive disadvantage. Such measures are insufficient to motivate the integrating behavior that is required within the enterprise let alone across the Extended Enterprise.

\section{Enterprise Measures:}

What distinguishes the technology focus in the enterprise view is the emphasis on external interconnectivity and internal linkages that support decision processes, transaction efficiency, and visibility within the firm and across its boundaries. ERP and CRM systems and other software solutions are employed to facilitate supply chain planning. An emphasis on cross-functional and cross-organizational process emerges although the focus primarily is still on the single firm. Mitigating risk (based on the total cost of ownership) is evident, and outsourcing is used mainly as a method to shift costs from fixed to variable. . The inherent structure remains somewhat bureaucratic but flatter-relying on an increased span of control. Multiple interactions at differing levels of the organization occur both upstream and downstream, mostly transactional efficiencies (firm wide) and some effectiveness measures (sometimes under the guise of EVA) are adopted. . Some empowerment appears but firms typically exist in more hierarchical structure where employees are undervalued and underutilized. Command and control is less but remains the default option. People necessarily develop broader and more analytical skills. What's in it for me and what's in it for you become parallel considerations. Some data exchange exists either through JIT or EDI but the full integration of supply chain wide systems is yet to be realized. Supply base reduction is viewed as a function of transaction efficiency and supply effectiveness since managers are beginning to incorporate thoughts of core competencies and relying on others to take over activities that they are better skilled.

The Supply Chain Council's SCOR Model provides some guidance on the types of metrics to get a balanced approach towards measuring supply chain performance. This model advocates a set of supply chain performance measures (see Table 2) combining the following: (1) Cycle time metrics (e.g., production cycle time and cash-to-cash cycle); (2) Cost metrics (e.g., cost per shipment and cost per warehouse pick); (3) Service/quality metrics (on-time shipments and defective products), and (4) Asset metrics (e.g., inventories).

\footnotetext{
2 The IndustryWeek Census of Manufacturers is a collaborative annual supply chain survey, focused on manufacturing, across multiple industries, conducted by the PWC's Management Consulting Services practice (now part of IBM Global Services) and IndustryWeek.
} 


\section{Extended Enterprise Measures}

Extended Enterprise measures are oriented toward achieving synthesized effectiveness based on based on notions of core competencies and sustainable competitive advantage. These concepts must be linked to economic valuation and entail both short-term and long-term process and results measures. With regard to technology, effective/efficient internal activities are essential because firms cannot link externally if they are unable to use the technology internally to connect all parts of the enterprise. The use of technology extends to enterprise software, demand forecasting and planning, e hubs, and other tools to tie all the members of the supply chain. Information sharing and visibility are essential for the extended enterprise to succeed. Customer-centric supply chains address core competencies and skills across the enterprise as a part of the strategy for bundled products and services to meet the needs of end-use customers. Metrics reflect concerns for the total cost of ownership and revenue enhancements across the enterprise and system-wide EVA are evident.

\section{Table 2: SCOR Performance Attributes Definitions}

\begin{tabular}{|c|c|c|}
\hline Performance Attribute & Performance Attribute Definition & Level 1 Metric \\
\hline \multirow{3}{*}{$\begin{array}{l}\text { Supply Chain Delivery } \\
\text { Reliability }\end{array}$} & \multirow{3}{*}{$\begin{array}{l}\text { The performance of the supply chain in delivering: } \\
\text { the correct product, to the correct place, at the correct } \\
\text { time, in the correct condition and packaging, in the } \\
\text { correct quantity, with the correct documentation, to } \\
\text { the correct customer. }\end{array}$} & Delivery Performance \\
\hline & & Fill Rates \\
\hline & & Perfect Order Fulfillment \\
\hline $\begin{array}{l}\text { Supply Chain } \\
\text { Responsiveness }\end{array}$ & $\begin{array}{l}\text { The velocity at which a supply chain provides } \\
\text { products to the customer. }\end{array}$ & Order Fulfillment Lead Times \\
\hline \multirow[t]{2}{*}{ Supply Chain Flexibility } & \multirow{2}{*}{$\begin{array}{l}\text { The agility of a supply chain in responding to } \\
\text { marketplace changes to gain or maintain competitive } \\
\text { advantage. }\end{array}$} & Supply Chain Response Time \\
\hline & & Production Flexibility \\
\hline \multirow[t]{4}{*}{ Supply Chain Costs } & \multirow[t]{4}{*}{ The costs associated with operating the supply chain. } & Cost of Goods Sold \\
\hline & & Total Supply Chain Management Costs \\
\hline & & Value-Added Productivity \\
\hline & & Warranty/Returns Processing Costs \\
\hline \multirow{3}{*}{$\begin{array}{l}\text { Supply Chain Asset } \\
\text { Management Efficiency }\end{array}$} & \multirow{3}{*}{$\begin{array}{l}\text { The effectiveness of an organization in managing } \\
\text { assets to support demand satisfaction. This includes } \\
\text { managing all assets: fixed and working capital. }\end{array}$} & Cash-to-Cash Cycle Time \\
\hline & & Inventory Days of Supply \\
\hline & & Asset Turns \\
\hline
\end{tabular}

Given the parallel investment in people and the emergence of trust and commitment, risk-taking behavior is a bit more evident as is a tendency to rely more on virtual integration rather than investing in vertical integration. Hierarchy is slowly being replaced by alliances where trust is viewed as important as a contract in building close ties across the supply chain. One can envision that the value of the network increases exponentially as the number of integrated partners increases across the Extended Enterprise. The emphasis for people (who patently develop business and general management thinking) is on relationship management. That is managers consciously look for win/win opportunities. Widely shared information (often transparent to the users) becomes the knowledge foundation for the Extended Enterprise. Closed loop systems based on information and knowledge are key to developing effective value relationships. Table 3 illustrates further some of the unique characteristics of the extended enterprise. By emphasizing a small set of criteria, we show that extended enterprise thinking is not business as usual and certainly is different from both a purchasing department and single firm perspective. While the objective of the firm is to increase its shareholder value through profitable growth, there are inherent differences between financial and operational performance measures. Businesses naturally focus on financial outcomes, while supply chains emphasize operational processes. One role of Extended Enterprise metrics is to resolve these differences.

Configuring extended enterprise metrics to support shareholder value is important. The challenge facing both financial and operational leaders is to translate financial objectives into real operating measures that push the Extended Enterprise to higher asset utilization and lower operating costs. PRTM's Performance Measurement 
Group uses cash-to-cash cycle time to relate financial and supply chain performance measures. ${ }^{3}$ An Extended Enterprise analytical framework that approaches asset management in this fashion achieves multiple objectives. Working capital requirements are expressed in a universally understood unit of measure and are process focused. This process performance metric can be readily decomposed into managerial meaningful performance measures that can be understood by all since time is the common denominator. Cash-to-cash cycle time cuts across both the organization and the Extended Enterprise. From upstream suppliers and sub-tier suppliers to downstream customers and ultimately to consumers and from accounting, through factories, and on to order management, cash-to-cash respects no organizational boundaries or functional silos. By following the material, money, and information flows, it captures in a single number the overall Extended Enterprise performance. To paraphrase an old finance adage, "profit is a number while cash is a fact." If the Extended Enterprise coordinates top-down cash-to-cash goals, all the enterprises' functions will align their continuous improvement activities in support of one another. Cash-to-cash cycle time helps focus the supply chain on a mutually agreed upon set of objectives The rate at which materials are converted into sold goods is not only a measure of a manufacturer's operating efficiency, but also of financial health. Leaders turn inventory four to five times faster than median performers ${ }^{4}$ and differentiate themselves by implementing practices such as collaborative forecasting with customers, formal continuous improvement, and predictive/preventative maintenance programs.

One PRTM client has achieved an asset utilization break through (Gailius and Ibarra, 2001) by making cash-to-cash cycle time a rallying point across the organization. Faced with a relatively stagnant marketplace and increased price pressure due to globalization, this worldwide manufacturing division endured a decade-long slide in profits and return on net assets (RONA). Losing patience, corporate headquarters cut funding for additional capital investment and began the process of "harvesting" the business. To ensure its survival, the division hammered home the cash-cash mindset throughout the entire supply chain and earned a reputation for unrivaled flexibility and responsiveness to customer requirements. Market share grew for the first time in five years, RONA improved, and the bottom line, the most important driver for shareholder value, began to grow. Instead of harvesting the division, the corporation began holding it up as an example of world-class supply chain performance.

An evolving supply chain management (SCM) framework is typically firm-centric with visibility and relationships constrained to immediate upstream and downstream supply chain partners. Adapting the Balanced Scorecard approach in such a fashion would necessarily relate the goals of SCM to customer satisfaction, firm financial performance, and the ways in which firms continue to learn, innovate and grow. This framework is depicted in Table 4. What distinguishes the metrics shown here is that they begin to focus on behaviors and situations that contradict the arm's length business practices that characterize most firms' long history of operating as a singular entity in uncoordinated transactional relationships.

The shift in philosophy that takes place when a supply chain point of view is embedded within the balanced scorecard framework is that the scorecard's internal perspective is expanded to include both the "inter-functional" and "partnership perspectives. In essence, the SCM Balanced Scorecard begins to force the incorporation of integrated measures, in addition to the traditional non-integrated measures, that motivate employees to view their firm's success as being predated upon the success of others in the supply chain rather than solely upon their firm itself. The cash-to-cash cycle is an example of an integrated measure that embraces several functions (accounting, manufacturing, logistics, and sales) across several different organizations. This type of integrated measure spans functional and firm boundaries to show all members how the chain (at least the immediate chain) is performing and fosters incentives to work with other members of the chain (Brewer and Speh, 2000).

\footnotetext{
3 That metric is the sum of days of sales outstanding (receivables) and inventory days of supply, less days of payables outstanding. Cash-to-cash cycle time is a simple and logical transformation of the traditional working capital concept, i.e., the time it takes a company to recoup its investment between paying for production materials and a customer paying for the received good or service.

4 IndustryWeek $4^{\text {th }}$ Annual Census of Manufacturers
} 
Table 3: A Comparative Analysis Of Enterprise Perspectives

Traditional Enterprise

\begin{tabular}{|c|c|c|c|}
\hline & Traditional & Enterprise & Extended Enterprise \\
\hline Technology & $\begin{array}{l}\text { Is either insider/outside or decision } \\
\text { support/transaction based } \\
\text { Mostly internal focused with both } \\
\text { Decision Support and transactions } \\
\text { Heavy transaction } \\
\text { (MRP, MRPII, DRP) }\end{array}$ & $\begin{array}{l}\text { Sourcing plus logistics } \\
\text { Internal DS tools and transaction } \\
\text { focus } \\
\text { Plus some attempt at external } \\
\text { opportunities } \\
\text { ERP_-internal connectivity } \\
\text { Collaborative network planning }\end{array}$ & $\begin{array}{l}\text { Effective/efficient internal } \\
\text { activities is a given and no } \\
\text { differential advantage } \\
\text { Enterprise software and e hubs } \\
\text { Full network optimization } \\
\text { Linkages are essential to play }\end{array}$ \\
\hline Process & $\begin{array}{l}\text { Cost reductions } \\
\text { Transaction focused } \\
\text { Risk avoidance to total cost of } \\
\text { ownership } \\
\text { Make vs. buy } \\
\text { Functionally-centric }\end{array}$ & $\begin{array}{l}\text { Risk mitigation TCO } \\
\text { EVA } \\
\text { Outsource } \\
\text { Some cross function/processes } \\
\text { Mainly from the firm's } \\
\text { perspective } \\
\text { Enterprise-centric }\end{array}$ & $\begin{array}{l}\text { TCO and revenue enhancement } \\
\text { EVA system wide } \\
\text { Core skills as part of strategy } \\
\text { bundled product/service process } \\
\text { attributes } \\
\text { Encourage risk-taking system } \\
\text { wide sharing } \\
\text { Learning system wide } \\
\text { Customer centric }\end{array}$ \\
\hline Structure & $\begin{array}{l}\text { Bureaucratic/hierarchical } \\
\text { Hybrid centralized/ } \\
\text { decentralized } \\
\text { Internally focused } \\
\text { Command and control } \\
\text { Manufacturing push-inventory } \\
\text { intensive }\end{array}$ & $\begin{array}{l}\text { Bureaucratic but flatter } \\
\text { Some empowerment } \\
\text { Virtual under utilization } \\
\text { Multiple interactions upstream } \\
\text { and downstream } \\
\text { Shared services internally } \\
\text { Mostly transaction efficiencies } \\
\text { Some effectiveness measures } \\
\text { Pull system through } \\
\text { internal/external providers }\end{array}$ & $\begin{array}{l}\text { Our SC/EE } \\
\text { Unnatural alliances } \\
\text { Non-B/H } \\
\text { Virtual ownership } \\
\text { Complex networks } \\
\text { Look to fill skills not to reduce } \\
\text { Fixed Costs } \rightarrow \text { to Variable Costs } \\
\text { Total network optimization }\end{array}$ \\
\hline People & $\begin{array}{l}\text { Purchasing/ buyers } \\
\text { What do you do for me } \\
\text { Some shift from price variance } \\
\text { Some strategic thinking } \\
\text { Internal supply chain training }\end{array}$ & $\begin{array}{l}\text { Less Command \& Control but it } \\
\text { remains the default option } \\
\text { Broader skills more analytical } \\
\text { Strong logistics lower the cost for } \\
\text { me/ you? } \\
\text { Inter-enterprise resource } \\
\text { utilization }\end{array}$ & $\begin{array}{l}\text { Win-win } \\
\text { Relationship mgmt } \\
\text { Business/GM thinkers } \\
\text { Enlightened self interest } \\
\text { Full network alignment }\end{array}$ \\
\hline Information & $\begin{array}{l}\text { Internally focused } \\
\text { Cross organizationally focused } \\
\text { Multiple sets of data } \\
\text { Builds on strategy to find supply } \\
\text { chain opportunities } \\
\text { Point solutions } \\
\text { Information = Power }\end{array}$ & $\begin{array}{l}\text { Some two way exchanges/sharing } \\
\text { Linkages for JIT/EDI } \\
\text { Linked internets } \\
\text { Internet-based extranet } \\
\text { Mostly workflow and some } \\
\text { planning information } \\
\text { Information is a bridge }\end{array}$ & $\begin{array}{l}\text { Widely shared } \\
\text { Transparent } \\
\text { Closed loop system } \\
\text { Information and knowledge key } \\
\text { Value relationships and } \\
\text { information } \\
\text { Full network, multiple channel } \\
\text { communication } \\
\text { Shared information is the } \\
\text { knowledge foundation }\end{array}$ \\
\hline Outcomes & $\begin{array}{l}\text { Rationalize supply base } \\
\text { Use to leverage cost } \\
\text { More efficient } \\
\text { Turnover high since skill sets } \\
\text { beginning to change } \\
\text { Transform role }\end{array}$ & $\begin{array}{l}\text { Expand supply to gain more } \\
\text { efficient use of working capital } \\
\text { and assets } \\
\text { Increased opportunity/challenges } \\
\text { for human capital } \\
\text { Some chain wide thinking and } \\
\text { information sharing }\end{array}$ & $\begin{array}{l}\text { Expand market access } \\
\text { Leverage financial assets } \\
\text { Operations excellence } \\
\text { Velocity } \\
\text { Look to customer and build } \\
\text { networks } \\
\text { Differentiated value chains } \\
\text { Unleash human capital from the } \\
\text { entire Extended Enterprise }\end{array}$ \\
\hline
\end{tabular}


Table 4: A Supply Chain Management Framework ${ }^{5}$

\begin{tabular}{|c|c|c|c|}
\hline SCM Goals & End Customer Benefits & Financial Benefits & SCM Improvements \\
\hline Waste reduction & Improved product/service quality & Higher profit margins & Product/process innovations \\
\hline Time compression & Improved timeliness & Improved cash flows & Partnership management \\
\hline Flexible response & Improved flexibility & Revenue growth & Information flows \\
\hline Unit cost reduction & Improved value & Higher return on assets & Threats/substitutes \\
\hline
\end{tabular}

The Balanced Scorecard recommends using executive information systems (EIS) that track a limited number of balanced metrics that are closely aligned to strategic objectives. While not specifically developed for Extended Enterprise performance measurement, Balanced Scorecard principles provide a good framework for developing and implementing the essential constructs. The approach would recommend that a small number of Extended Enterprise measures be tracked based along four perspectives:

- $\quad$ Customer Perspective (e.g., on-time delivery and order fill rate)

- $\quad$ Financial Perspective (e.g., cost of manufacturing and cost of warehousing across the extended enterprise)

- $\quad$ Internal business perspective (e.g., manufacturing adherence-to-plan and forecast errors)

- Innovative and learning perspective (e.g., ISM- and APICS-certified employees and new product development cycle time)

To begin the process of creating an Extended Enterprise Scorecard, partners must agree on a more comprehensive set of metrics to reflect a value chain-wide perspective. Understanding the customer value proposition is the starting point.

\section{Consumer Value}

Consumer and customer current and future needs should drive the Extended Enterprise; after all, this is the basic reason for an integrated supply chain. Market focused thinking would force consideration to the segment level since differences in decision processes, attribute/benefit importance and such are managed at the segment level. Mass customization and differentiated products and services offer enterprise opportunities to value consumers (and customers) more as individuals. In some instances, we can think about segments of one. To achieve these goals data mining will necessarily form the front-end for real-time, fact-based enterprise-wide decision-making. Equally important is the need to ensure that this information is shared supply chain wide.

One major challenge facing all supply chains is fulfillment (on-time delivery) and it is increasingly becoming a critical success factor for manufacturers and service providers alike. In fact, $92 \%$ of corporate executives consider just-in-time delivery by their suppliers to be critical to achieving "world-class" manufacturing status. Almost two-thirds of the manufacturers have an on-time delivery performance of at least $90 \%$. Leaders are able to achieve higher than $99 \%$ on-time delivery performance ${ }^{6}$. If one extrapolates these numbers to a typical Extended Enterprise, one that might be comprised of five partners in serial (comprised for example of a raw material supplier, a component supplier, an assembler, a distributor and a retailer), the results are startling. The end-to-end delivery performance for an Extended Enterprise with five such members performing at a $90 \%$ on-time delivery level would be only 59\% (90\%) $)^{5}$. To qualify as a "world class" Extended Enterprise, each of the five members would have to attain individual on-time delivery performances of $99.8 \%$.

\section{Financial Benefits}

For the Extended Enterprise, sustained revenue will come from customizing existing product platforms for small batches of discrete, differentiated products and services; differentiated products and services for new markets; and the introduction of new product and service platforms. Yet, ROI still will remain a key financial measure across

\footnotetext{
5 Adapted from Brewer and Speh, 2000.

6 IndustryWeek $4^{\text {th }}$ Annual Census of Manufacturers
} 
the supply chain. Some financial analysts advocate estimating a company's return on capital or economic valueadded. These metrics are predicated no the premise that shareholder value increases when a company earns more than its cost of capital. One such measure, Economic Value Added (EVA), developed by Stern, Stewart, and Company, theoretically attempts to quantify value created by an enterprise, basing it on operating profits in excess of capital employed (through debt and equity financing), although, in practice, even companies who advocate such a measure rarely consider anything that occurs outside their own "four walls". These metrics have a broad applicability to capture an enterprise's value added contributions, particularly when they are employed to motivate enterprise-wide behaviors that optimize working capital and asset efficiency and tax and transfer pricing, enhance revenue opportunities as well as the more traditional views around reducing value chain costs. As noted earlier, two financial metrics presented by Brewer and Speh (2000) fully reflect the set of performance measures that support and encourage Extended Enterprise thinking. The cash-to-cash cycle time and total cost of ownership metrics are examples of integrated measures that embrace several functions (accounting, manufacturing, logistics, and sales) across more than one business firm. This type of integrated measure spans functional and firm boundaries to show all members how the chain is performing and fosters incentives to work with other members of the chain.

However, firms must also consider performance metrics that help measure the degree of collaboration, trust, commitment and related behaviors that are necessary in the Balanced Scorecard approach for the Extended Enterprise. The objective is to understand the extent to which the different supply chain members engage in appropriate behaviors that re-enforce and bolster the principles and ideals of the extended enterprise. The challenge is to ensure that senior management understands the strategic importance of this type of metric and is willing to accept more behavioral measures to help determine supply chain success. Equally important, they must be willing to invest in training and education to develop supply chain managers who have the requisite skills implied by these metrics. As stated in preceding chapters, this is a non-trivial challenge. These metrics carry very significant changes for the traditional OEM or supplier. For example, managerial mindsets will have to changes across a number of dimensions, ranging from: (1) functional to process integration, (2) information hoarding to information sharing, (3) adversarial to collaborative behavior, and (4) customer service to relationship management.

\section{Operations Within The Extended Enterprise:}

The Extended Enterprise "operational" perspective emphasizes both internal and external processes and embraces lean operations and agile manufacturing/service delivery. These operations optimize time, quality, and cost and make informed tradeoff decisions across the Extended Enterprise from womb to tomb. Every operation can trace its individual contributions to the enterprise's strategic goals and profitability. The Kano model suggests that today's delights are tomorrow's expectations, and the enterprise's products and processes that are leading edge today will be obsolete tomorrow. Therefore, those investments should provide a profit quickly. Break-Even Time is the time in which revenues from a product or attributable to a process have returned the original investment and are starting to produce a profit. This assertion assumes that products and services are priced on total expected sales and average unit lifecycle costs, not on first cost. Considering external processes raises the level of analysis from the firm and its internal functions to the supply chain. The objective is to supplement traditional internal processes with other processes that are unique to managing the workflow, cash flows, and information flows across the Extended Enterprise. Two critical areas need to be assessed:

- $\quad$ The degree of synchronicity/complementarity of key business processes across all supply chain partners: This would include processes for managing inventory, workflow, and the like; processes for improving quality, time to market and all aspects of the new product development and innovation, and processes for information gathering and knowledge management, across all firms. Other process- related metrics might relate to mechanisms for resolving conflict and serious disagreements.

- The relationship-specific measures that must lie at the heart of the extended enterprise: For example, it is essential that measures exist for estimating the degree of collaboration, trust and commitment, as well as level of perceived conflict. These qualitative metrics would reflect much of the behavior in the extended enterprise and help ensure the full and dedicated involvement of trading partners. 
Another external process implication is to highlight those processes that affect each supply chain member and to address those having a profound impact on how well the Extended Enterprise performs relative to other competing networks. Demand and supply forecasting processes, technology sharing, cross supply chain learning and knowledge transfer all improve the shared information accuracy, ensure a common world view and lead to firmlevel improvements that are a function of system-wide effects. Moreover, these processes likely lead to a common vision and concomitant alignment of the goals and objectives across the Extended Enterprise. Table 5 illustrates external process measures.

Table 5: External Process Measures For The Extended Enterprise

\begin{tabular}{ll|}
\hline & Compatibility of software systems that span the supply chain \\
- & Time taken to implement supply chain wide IT changes \\
- & Processes to ensure shared strategic plans at all levels \\
- & Average time to develop and implement new product/services \\
- & Processes to ensure that relevant technology and knowledge is shared supply chain-wide \\
\hline
\end{tabular}

\section{Learning and Growth}

Learning and growth present a sense of the Extended Enterprise's readiness to accept and master change. The Extended Enterprise succeeds, if not survives, based on teaming - within and across organizational, geographical, functional, and process boundaries. And as teaming is a learned skill, Extended Enterprises will want a work force that is skilled in teaming. In his highly revealing automotive industry study, Jeffrey Dyer showed that specific buyer and supplier behaviors led to higher levels of mutual trust, which in turn resulted in lower transaction costs, higher ROI, greater knowledge sharing and higher levels of dedicated asset investments. Dyer distinguishes between interpersonal trust (between two individuals) and inter-firm trust (between groups of individuals); he found that U.S. suppliers trust Toyota more than they trust U.S. automakers, not because of greater levels of interpersonal trust, but because they find Toyota's business processes for working with suppliers to be fairer and more consistent. Dyer refers to this process-based trust as critical for creating a trust orientation between individuals in large organizations. He notes that a firm is viewed as trustworthy when it has institutionalized a set of practices and routines (i.e., business processes) for dealing with a partner organization that transcend the influence of particular individuals. Dyer found that key processes that can either foster or destroy supplier trust include the automaker's supplier selection process and the processes by which automakers transfer knowledge to suppliers to help them improve productivity and quality. Thus, measures and metrics that indicate the effectiveness of such critical processes contribute vitally to the success of the Extended Enterprise.

In the final analysis, the effective Extended Enterprise will be one that its stakeholders - customers, partners, suppliers, shareholders, and employees - can trust to meet or exceed its commitments and to act reliably and constructively as conditions change. In this context Trustworthiness reflects the ability of the Extended Enterprise to address issues over which they should have had control while Robustness measures the capability to readily adapt to those changing market environmental conditions that might not normally have been anticipated.

\section{An Extended Enterprise Balanced Scorecard}

Table 6 adapts the Balanced Scorecard Metrics (Kaplan and Norton, 1996 and Jordan and Michel, 2000) for the Extended Enterprise. Most enterprises will jointly determine an appropriate metrics subset as the barometers for measurements. The important thing is to pursue some balance between financial and other metrics that reflects the Extended Enterprise vision and that can be used to motivate the desired behaviors across and within the 
Enterprise and at all organizational/individual as well as functionary and process levels. Such an approach incorporates several benefits:

- It emphasizes the inter-functional and inter-firm nature of the Extended Enterprise and recognizes re need to ascertain the extent to which firms effectively work together

- The framework will increase the chance that a "balanced" management approach is indeed practiced within the Extended Enterprise

- $\quad$ Pursuing such measures will stimulate adopters to develop other Extended Enterprise measures perhaps more suited to unique aspects of their situation

- Use should help individuals focus attention on achieving goals that supercede the typical measures of performance used within firms

\section{Achieving Extended Enterprise Goals}

Historically, most companies have focused their performance measurement on achieving functional excellence, particularly financial excellence. With the advent of the Extended Enterprise mindset, many have objectives to increase their degree of extended enterprise-wide integration. Achieving Extended Enterprise goals will best be served by designing the enterprise activities jointly. Assuming the activities are well (and jointly) designed leaves the necessity to track them, execute against them and ultimately attain the desired results. The manner in which the Extended Enterprise conducts performance management can support or inhibit the realization of its goals. The Extended Enterprise performance management system needs an activity (or process) view - i.e., is the activity making the contributions it should? Equally as important, however, is an enterprise (or results) focus i.e., is the totality of the Extended Enterprise's activities achieving the Enterprise goals? An extended enterprisewide performance management system that helps to maximize enterprise outcomes while minimizing inputs necessarily creates competitive advantage. To this end, it is absolutely essential to understand the explicit correlation between the activities and the results and to make Enterprise-wide decisions accordingly.

The Extended Enterprise also has to adopt agile performances management strategies, i.e., they should be designed so they can readily adapt to unpredicted change. These strategic Extended Enterprise measures must also place as much emphasis on the readiness for future competition as they do on the financial measurements necessary for today. The Extended Enterprise Balanced Scorecard provides such a framework. It helps create commitment among managers along the supply chain since they were part of the process to create these measures. In addition, the BSC helps promote the sharing of best practices and stimulates communications up and down the value chain. The entire process is linked and individual behavior is aligned with the goals of the extended enterprise. Cascading scorecards begin with the extended enterprise level metrics and end with the individual managers' scorecards in support of the extended enterprise. Since there is a common knowledge base across the supply chain, it is easier to fix problems and implement change consistent with mutually agreed-upon goals.

Overall, the within the Extended Enterprise performance management system must: (1) identify the cost of resources and investments consumed in performing significant enterprise activities; (2) determine the efficiency and effectiveness of the activities performed and the resources used; and (3) identify and evaluate new activities that can improve the future performance of the Extended Enterprise. Although many different measures have been discussed here, the metrics chosen for a particular application should be relatively few in number, easy to measure, fairly high level, and discernable in real time. Metrics that are hard to measure, totally retrospective and obtuse (i.e., the impact on supply chain wide performance is difficult to appreciate) are of little use and ultimately can affect the usefulness of the scorecard.

\section{Lessons Learned}

- $\quad$ Measurements are important to directly controlling behavior and indirectly to performance

- $\quad$ Extended Enterprise measures must be aligned to enterprise-wide strategic objectives

- $\quad$ A few key measurements will go a long way toward keeping the Extended Enterprise on track to achieving enterprise wide improvement objectives 
- $\quad$ Seemingly relevant, but cumbersome, measurements are of little use, and are possibly a hindrance, in helping to improve supply chain performance

- $\quad$ Picking the wrong measures and leaving out the important ones could lead to Extended Enterprise performance degradation

- Driving the Extended Enterprise based on after-the-fact measures, like losing an important customer or having poor financial performance is not very effective.

Table 6: The Comprehensive Extended Enterprise Balanced Scorecard

\begin{tabular}{|c|c|c|c|c|c|}
\hline Financial & Customer & Operations & $\begin{array}{c}\begin{array}{c}\text { Learning \& } \\
\text { Growth }\end{array} \\
\end{array}$ & Globalization & Innovation \\
\hline ROI & $\begin{array}{l}\text { Revenue Growth } \\
\text { by Market } \\
\text { Segments and } \\
\text { Product/Service } \\
\text { Lines }\end{array}$ & $\begin{array}{l}\text { Operations } \\
\text { cycle time }\end{array}$ & $\begin{array}{l}\text { Teaming } \\
\text { Qualification } \\
\text { Level and } \\
\text { Percentage } \\
\text { Qualified }\end{array}$ & $\begin{array}{l}\text { Market and } \\
\text { Major Account } \\
\text { Share by } \\
\text { Geographic } \\
\text { Region }\end{array}$ & $\begin{array}{l}\text { R\&D and Market } \\
\text { Development Investment } \\
\text { (percentage of revenue) }\end{array}$ \\
\hline $\begin{array}{l}\text { Earnings } \\
\text { Change/ } \\
\text { Invested } \\
\text { Dollar }\end{array}$ & $\begin{array}{l}\text { Net Profit by } \\
\text { Customer or } \\
\text { Segment }\end{array}$ & $\begin{array}{l}\text { Break-Even } \\
\text { Time }\end{array}$ & $\begin{array}{l}\text { Cost/Time of } \\
\text { Training/ } \\
\text { Retraining }\end{array}$ & $\begin{array}{l}\text { Market } \\
\text { Penetration by } \\
\text { Geographic } \\
\text { Region }\end{array}$ & $\begin{array}{l}\text { Earnings Attributable to } \\
\text { Innovations }\end{array}$ \\
\hline $\begin{array}{l}\text { Turnover } \\
\text { Rate }\end{array}$ & $\begin{array}{l}\text { Customer } \\
\text { Perceptions }\end{array}$ & $\begin{array}{l}\text { Percentage of } \\
\text { Six-Sigma } \\
\text { Designs }\end{array}$ & Trustworthiness & $\begin{array}{l}\text { \%of Employees } \\
\text { Engaged in } \\
\text { Trans-national } \\
\text { Teaming }\end{array}$ & $\begin{array}{l}\% \text { of Compensation } \\
\text { Attributed to Innovation } \\
\text { Contributions }\end{array}$ \\
\hline Margin & $\begin{array}{l}\text { Total Lifecycle } \\
\text { Costs }\end{array}$ & $\begin{array}{l}\text { First-Pass } \\
\text { Yields }\end{array}$ & Robustness & $\begin{array}{l}\text { Percentage of } \\
\text { Systems } \\
\text { Integrated }\end{array}$ & $\begin{array}{l}\text { Relative Average } \\
\text { Product/Process Lead (or } \\
\text { Lag) Times }\end{array}$ \\
\hline $\begin{array}{l}\text { Percentage } \\
\text { of Revenues } \\
\text { from New } \\
\text { Products, } \\
\text { Services \& } \\
\text { Markets }\end{array}$ & Fill Time & $\begin{array}{l}\text { Productivity } \\
\text { Improvement } \\
\text { Rate }\end{array}$ & $\begin{array}{l}\text { Decision-making } \\
\text { Rate }\end{array}$ & $\begin{array}{l}\text { Information } \\
\text { Systems } \\
\text { Availability }\end{array}$ & $\begin{array}{l}\text { Average Product/Process } \\
\text { Development Time }\end{array}$ \\
\hline $\begin{array}{l}\text { Average } \\
\text { Payback } \\
\text { Time }\end{array}$ & On-time Delivery & $\begin{array}{l}\text { Accuracy and } \\
\text { Completeness } \\
\text { of Information } \\
\end{array}$ & $\begin{array}{l}\text { Information } \\
\text { Systems Literacy } \\
\text { Rate }\end{array}$ & & \\
\hline $\begin{array}{l}\text { Revenue per } \\
\text { FTE }\end{array}$ & MTBR & $\begin{array}{l}\text { Time to Obtain } \\
\text { Product or } \\
\text { Project Status }\end{array}$ & & & \\
\hline $\begin{array}{l}\text { Relative } \\
\text { Costs }\end{array}$ & & $\begin{array}{l}\text { Cost of Scrap } \\
\text { and Rework } \\
(\% \text { of sales })\end{array}$ & & & \\
\hline
\end{tabular}

\section{References}

1. Bossidy, Larry and Ram Charan, Execution: The Discipline of Getting things Done, New York: Crown Business, 2002.

2. Brewer, Peter C. and Thomas W. Speh, "Using the Balanced Scorecard to Measure Supply Chain Performance", Journal of Business Logistics, 21, no. 1, 2000, pp 75-93.

3. Davis, Edward and R. Spekman, The Extended Enterprise: Gaining Competitive Advantage Through Supply Chain Alliances and Partner Leverage, Prentice Hall- Financial Times, 2004.

4. $\quad$ Dyer, Jeffrey H., Collaborative Advantage, Oxford University Press, 2000.

5. Gailius, Sheila and Paul Ibarra, "Configuring Supply Chain Metrics to Support Shareholder Value", Insight, Summer/Fall 2001, pp 50-51. 
6. Jordan, James A. Jr., and Frederick J. Michel, Next Generation Manufacturing: Methods and Techniques, New York: John Wiley \& Sons, 2000.

7. Kaplan, Robert S. and David P. Norton, "The Balanced Scorecard - Measures that Drive Performance", Harvard Business Review, January-February 1992.

8. Keebler, James S., Karl B. Manrodt, David A. Durtsche, and D. Michael Ledyard, Keeping Score: Measuring the Business Value of Logistics in the Supply Chain, Oak Brook, IL: Council of Logistics Management, 1999.

9. Means, Grady and David Schneider, Meta Capitalism, New York: John Wiley and Sons, 2000.

10. Measuring and Improving Productivity in Physical Distribution, National Council of Physical Distribution Management, 1984.

11. Monczka, Robert M. and James P. Morgan, “Today's measurements just don't make it!”, Purchasing, April 21, 1994, pp. 46-50.

12. Senge, Peter M., The Fifth Discipline: The Art \& Practice of the Learning Organization, New York: Doubleday Currency, 1990.

13. Tyndall, Gene, Christopher Gopal, Wofgang Partsch, and John Kamauff, Supercharging Supply Chains: New Ways to Increase Value through Global Operational Excellence, New York: John Wiley and Sons, 1998. 
Notes 